\title{
How to Improve the English Listening and Speaking Teaching Level by Strengthening the Second Classroom
}

\author{
Fang Wang \\ School of Foreign Language, Haikou College of Economics, Haikou, \\ Hainan, 570311, China
}

\begin{abstract}
For the teaching of English major, the effectiveness of listening and speaking teaching has become a major problem for English teaching, the unity of classroom teaching methods make the students interest in learning is relatively low, there is no great breakthrough in the teaching quality. In the new curriculum reform, the school classroom teaching is also constantly reform, new teaching methods are used in classroom teaching, promote the development of second classroom teaching in order to improve the listening and speaking teaching level of English majors. Nowadays, the development and application of computer information technology have greatly changed the school teaching, and the information technology has promoted the further development of English second classroom teaching. The second classroom development also needs the common support of the school, family and society to create a good learning environment in English. In addition, it also effective to carry out listening and speaking activities of the second classroom to improve English listening and speaking teaching level Keywords: English majors; second class; listening and speaking teaching; good environment
\end{abstract}

\section{Introduction}

In English teaching, listening, speaking, reading, writing and translation are the basic skills that English majors must master, and they must master the basic skills, but through years of teaching, teachers pay attention to students' basic skills , 
While ignoring the overall quality of the students, making English majors of English learning interest gradually decreased, the quality of English teaching is also declining, especially in English listening and speaking teaching, there is a bottleneck in teaching, English major Teachers also fall into the dilemma of teaching. In order to improve the teaching level of English majors, English teachers are required to change their teaching concept and implement innovation and reform measures. They will be taught as the focus of English teaching, while those of English majors will serve the teaching of listening and speaking.

In addition, the first classroom teaching of English major to basic teaching, and the second classroom as an extension of the first class, mainly in the main teaching and listening and speaking, and activities in teaching, so that students interested in English teaching, and then learn of the content used in practice.

\section{The limitations of English listening and speaking teaching}

In order to increase the connection between China and other regions, it is necessary to cultivate the spoken English of the English majors in order to increase the relationship between English and other areas. In this way, the English is becoming more and more important in the international community. Communicative competence as the focus of teaching, but English listening and speaking teaching of English there are still many problems that need in-depth study.

\subsection{English teaching time is relatively short, the teaching content is extremely limited}

According to the analysis of the requirements of English curriculum, there are two oral English courses in many undergraduates. In a short period of time, teachers can not put a lot of oral English knowledge into classroom teaching. A short time it is difficult to grasp too much learning content [1]. Therefore, whether students master the degree of knowledge, or the performance of teachers' guidance and feedback, can not have enough time to solve. Therefore, students practice time is limited and the quality of oral English teaching has also been greatly affected.

\subsection{Students are lack of initiative in English teaching}

In the traditional English teaching, the teacher will English listening, speaking, reading and writing skills as the focus of classroom teaching to implement, and teaching a single, relatively boring classroom atmosphere, making students in English learning lack of initiative. In addition, because of the long-term students in the examination-oriented education model under the influence of relying on a relatively heavy heart, so rely on teachers in oral English teaching, coupled with the previous dumb English teaching, making students lack confidence in English learning, fear of oral expression errors, students' initiative is not enough. 
2.3 The number of classes is not conducive to students improving the quality of spoken language teaching

In recent years, with the increasing phenomenon of Chinese college enrollment, the increasing number of class teaching, at present, college English classes in the number of about 30 people, has not yet reached the ten small class oral teaching scale. In a large number of cases, even if the English teacher designed a lot of group activities teaching, but can not be done for each student guidance, and thus the student feedback is not comprehensive, and in general will affect the quality of oral teaching [2].

\section{The theory basis to carry out the second classroom of English listening and speaking teaching}

Oral English teaching mainly focuses on cultivating students 'communicative competence, while the traditional teaching does not pay attention to the development of students' comprehensive ability, so students do not have a strong interest in English learning. After the second classroom teaching mode is put forward, clear teaching objectives and diverse teaching modes will create a good learning atmosphere for students and encourage students to cultivate good study habits in English learning and arouse students' initiative and creativity.

\subsection{The Second classroom teaching teachers can provide students with more teaching resources}

For oral English teaching, first of all students to have sufficient knowledge of English, only to master the basic knowledge of English, in order to further the development of teaching. At the same time, the second classroom learning can not be time and place constraints, students can use extra-curricular time to learn, and to practice speaking, this broke the English professional students' two weekly oral class restrictions, thereby enhancing the students' oral practical ability. Moreover, teachers can provide students with sufficient learning materials to change the time constraints of traditional classroom teaching, teachers will be learning content published in the second classroom learning environment, students can choose according to their own interests related to learning content, and then use After-school time and teachers to explore learning.

\subsection{Teachers can create a good learning communication environment for students}

Oral teaching mainly train students' listening and speaking ability and good language environment plays a very important role in students' learning. Using context teaching and cooperative learning can promote the students' initiative and exert their enthusiasm and enthusiasm [4]. The premise is that teachers use the second classroom to provide students with a good communication environment 
and English conversation scenarios, so that students learn in the session to create new teaching ability.

\subsection{The second classroom can develop students' self-learning ability}

Foreign language teaching mainly aims at cultivating students' communicative competence, and at the same time, the students have the ability to learn independently. Therefore, the teaching of the second class is more relaxed and free. Students can master the knowledge of English while participating in the activities. As the learning environment is relatively free, teachers in the second classroom teaching to develop students' interest in learning, students have a strong interest in English learning, student learning initiative will be mobilized, and thus the initiative of students to learn will continue to upgrade.

\section{Create a good environment for the English listening and speaking ability teaching}

The second classroom mainly activities teaching, teachers for students to create a variety of teaching situations, students can practice through situational dialogue and listening and speaking ability, because the second classroom teaching is not time and place constraints, therefore, students learn English in the process But also get the social, family, school and other aspects of support for the second classroom teaching and learning to create a good teaching environment.

The school is one of the main environments for students to learn, and the school classroom is also the first classroom of English teaching, but also the students learn the basics of English basic place. For teachers, the teacher should be responsible for teaching English, teaching English during the course to enhance students' listening and speaking ability training, including English classroom teaching design and English classroom teaching plan for students to provide a favourable learning environment for students' English learning to the international direction..

In addition to the school to provide students with a good learning environment, the family can also provide students with a good learning environment, parents in addition to providing funds for students, but also for the students to increase investment in the emotional, so teachers to support students Participate in the activities of the second class, and help students to actively prepare the activities required materials and students through the cooperation with parents feel the support of parents, then the mentality and purpose of student learning will change, under normal circumstances, Student learning initiative will be further improved. 


\section{Effectively carrying out listening and speaking English major second classroom teaching activities}

\subsection{The second class enhance students' listening and speaking ability through the development of independent activities}

In English teaching, to carry out autonomous teaching activities help students improve their listening and speaking ability, for English majors, the basic knowledge of English is that they must have the knowledge reserves, therefore, the most basic ability to remember is essential.

In addition to the students consciously seize the early reading time, many college campus radio programs have English programs, students can listen to the campus radio program to increase the ability of listening and speaking training, or students can be recorded in classroom teaching as English listening and speaking skills to practice the material, in order to consolidate classroom learning content. Students can also learn how to use the Internet to find out what they are interested in. They can learn the time and progress of their study and improve the quality of their learning.

\subsection{The second class through cooperative activities to improve English listening and speaking teaching}

In today's society's economic development process, the team spirit is a very powerful force, both to enhance student learning efficiency, but also allow students to have a sense of cooperation, the students after learning and development has a certain role. In college English teaching, teachers in the second classroom teaching cooperation activities, in order to enhance students' English listening and speaking. The main activities are English Corner or the organization of students to set up the English Association, can also organize students to participate in various large-scale competition activities.

English Corner or English Club is the second common classroom practice in English. Its organizers can be both students and English teachers. The learning environment of English Corner is more relaxed. It mainly focuses on spoken and spoken English, to overcome the psychological barriers, with the help of teachers in English conversation. English Association is mainly organized by the English lover together, its activities are mainly community activities, the purpose is to provide a platform for the exchange of learning English enthusiasts, these activities are done by the team, requires a lot of manpower to collaborate.

\subsection{The Second classroom can also hold human activities, so that students can enhance the English listening and speaking ability}

English teaching is mainly for students interested in learning English, but also students in English learning not only able to train listening and speaking ability, but also to learn more about cultural knowledge. Schools use the second class of humanistic activities, is to enable students to use English knowledge while also 
improving their skills. For example: the activities of the school English cultural festival, English evening and other activities, the most interesting for students is the voice of English film activities, in the process of participating in activities, students not only to imitate, But also read, talk, these activities include the ability of English listening and speaking training, and thus can comprehensively enhance the ability of listening and speaking English.

\subsection{The second classroom can also hold more practical activities}

The purpose of students 'learning knowledge is to use knowledge. Their knowledge of scientific and cultural knowledge determines the level of their use of knowledge. Therefore, the role of students' practical activities in English teaching is very important. Schools can allow students to participate in practical activities in designated schools or communities, or in the professional cooperation with the school counterparts in the practice of business training. As students participate in internship activities, the leadership in the work for the students to arrange for professional quality corresponding to the practical work, not only simple, but also exercise English listening and speaking ability, therefore, students English ability to get a comprehensive exercise.

\section{Conclusion}

As the first classroom of English teaching, students in the classroom mainly study the basic knowledge of English, and in the second classroom teaching, students' listening and speaking ability, unity consciousness and so on can be maximized enhanced. Therefore, in order to improve students 'English listening and speaking ability in the second classroom teaching, it is necessary to create a good learning atmosphere for the students for schools and families and to promote students' interest in the second classroom English teaching.

\section{References}

[1] Luo Huan. English-speaking Second Classroom Based on Listening and Speaking. Guangxi Education College, 55(12), pp.68-70, 2011

[2] Chai Yangli. Study on Non-English Majors' Listening and Speaking Learning Request Based on WeChat. Foreign Language Teaching, 8 (5), pp.87- 91, 2013

[3] Chai Yangli. An Empirical Study on English Listening and Speaking Learning of Non-English Majors Based on WeChat. Audio-Visual Education Research 12(10), pp. 18- 20, 2012

[4] Xu Zhuoyi, Han Yinyan. The thinking and countermeasure on the cultivation of English majors' practical ability in the second class. Jiliang Institute of Chemical Technology, 9(6), pp.58- 61, 2011

[5] Dan Jin. Research on the Concept and Approach of Humanistic Quality Education for English Majors in Applied Undergraduates - Based on the Construction of English Second Class Practical Teaching System, 8(4), pp.85-87, 2014 